\title{
Assessment of permeability of eroded dentin after the use of universal, self-etch, and conventional systems
}

\author{
Fábia R. V. O. Roma', Karla J. S. Penha', Carlos R. G. Torres², Etevaldo M. Maia-Filho³, Leily M. \\ Firoozmand' \\ 1. Federal University of Maranhão, Dentistry Department, São Luis, MA, Brasil. \\ 2. Paulista State University- Institute of Science and Technology, Restorative Dentistry Department, São José dos Campos, \\ SP, Brasil. \\ 3. CEUMA University, Endodontics Department, São Luís, Maranhão, Brasil.
}

\begin{abstract}
Dentin hypersensitivity is caused by increased dentinal permeability due to total or partial exposure of dentinal tubules, which in turn can be produced by alterations of dental structures or failure of restorative procedures. The purpose of this in vitro study was to evaluate the efficacy of the application of different kinds of adhesive systems to prevent dentin permeability before and after an erosive challenge. Fifty bovine dentin discs (6x1 $\mathrm{mm}$ ) were prepared and the specimens were divided into 5 groups ( $n=10)$ : (SB2) Single Bond 2, (SBU) Universal Single Bond, (CSB) Clearfil SE Bond, (SM) Scotchbond Multipurpose and (C) Control. Hydraulic conductance of dentin was recorded after adhesive application (HC-1) and after erosive challenge (HC-2). Dentin surface images of post-treatment and post-erosive challenge were obtained by scanning electron
\end{abstract}

microscopy (SEM). Data were analyzed using Kruskal Wallis, Mann-Whitney with Bonferroni correction and Wilcoxon tests $(p<0.05)$. Reduction in dentin permeability was observed with the application of adhesive systems $(p<0.05)$. After the erosive challenge, dentin permeability increased for $S B U$ and CSB $(p<0.05)$, while SB2 and SM did not differ in $\mathrm{HC}-1$ or $\mathrm{HC}-2$ $(p>0.05)$. The conventional, self-etching and universal adhesive systems reduce dentinal permeability by more than $80 \%$, and dentin demineralization may contribute to the increased permeability of universal and self-etching systems.

Received: October 2020; Accepted: December 2020.

Keywords: dentin - dentin bonding agents - dentin permeability - tooth erosion.

\section{Avaliação da permeabilidade da dentina com erosão, após o uso de sistemas universais, autocondicionantes e convencionais}

\begin{abstract}
RESUMO
Diversos pacientes apresentam hipersensibilidade dentária ou falha nos procedimentos restauradores, devido à exposição total ou parcial de túbulos dentinários. O objetivo deste estudo in vitro foi o de avaliar a influência da aplicação de diferentes tipos de sistemas adesivos na permeabilidade da dentina e após o desafio erosivo. Cinquenta discos de dentina bovina ( $6 \times 1 \mathrm{~mm})$ foram confeccionados e os espécimes foram divididos em 5 grupos $(n=10)$ : $(S B 2)$ Single Bond 2, (SBU) Universal Single Bond, (CSB) Clearfil SE Bond, (SM) Scotchbond Multiuso e (C) Controle. A condutância hidráulica da dentina foi registrada após a aplicação do adesivo (HC-1) e após o desafio erosivo (HC-2). Imagens da superfície da dentina de pós-tratamento e pós-desafio erosivo foram obtidas por microscopia eletrônica de varredura (MEV). Os dados foram analisados pelos testes
\end{abstract}

de Kruskal Wallis, Mann-Whitney com correção de Bonferroni e Wilcoxon $(p<0,05)$. Redução da permeabilidade dentinária foi observada com a aplicação dos sistemas adesivos $(p<0,05)$. Após o desafio erosivo, a permeabilidade dentinária aumentou para $S B U$ e CSB $(p<0,05)$, enquanto SB2 e SM não diferiram em HC-1 e HC-2 ( $p>0,05)$. Os sistemas adesivos convencionais, autocondicionantes e universais reduzem a permeabilidade dentinária em mais de $80 \%$, e a dentina desmineralizada pode gerar um aumento da permeabilidade dos sistemas adesivos universais e autocondicionantes.

Palavras-chave: dentina-adesivos dentinários-permeabilidade da dentina - erosão dentária. 


\section{INTRODUCTION}

Numerous clinical conditions may affect dentin and the permeability of the dentinal complex. Dentin permeability involves the passage of fluids, ions, molecules, particles and bacteria through dentinal tubules and can be modified by different oral conditions. Physiologically, this is a very evident mechanism that enables the transport of nutrients and pulp impulses through dentinal tubes via odontoblasts, influencing the maintenance of vitality of the dental tissues ${ }^{1}$.

Clinically, dentinal tubules may be exposed due to pathological conditions such as loss of enamel, inducing the presence of erosive or abrasive dentin exposure and gingival recession, presence of caries, cracked tooth, ${ }^{2}$ or even due to cavity preparation for direct/indirect restorations ${ }^{3}$. Adhesive systems are presented as a relatively effective material for sealing exposed dentinal tubules, acting through the formation of the hybrid layer ${ }^{4}$. Resin materials may thus be indicated both for protecting pulp against exposure to bacterial products between the period of dental preparation and cementation of the final indirect restoration (prehybridization) ${ }^{3}$, and for dentin hypersensitivity ${ }^{2}$ in non-carious cervical lesions (NCCL). Hybrid coatings can be alternative for the treatment of clinical dentin hypersensitivity because they form a thin, colorless film on the dentin, ${ }^{5}$ reducing the communication between the external environment and the pulp.

However, the formation and maintenance of the hybrid layer are objects of investigation, ${ }^{4,}{ }^{6}$ because the technique is challenging due to the complexity of the dentin tissue. Moreover, the hybrid layer is subject to protein and hydrolytic degradation ${ }^{4,6}$.

Single-bottle or multi-bottle adhesives, either selfetching or total-etch, are employed for the dentin treatment. The behavior of these materials varies according to the type of adhesive system used. The single-step self-etching adhesives appear to allow fluid conductance in vitro similarly or slightly more than dentin covered by the smear layer ${ }^{7}$. Transmission electron microscopy reveals the formation of water trees in single-step self-etching adhesives, which facilitate water movement through the polymerized adhesives, making them highly permeable ${ }^{7}$. In contrast, better dentin surface sealing ${ }^{3}$ has been observed in 3-step total-etch or 2-step self-etching adhesive systems, because the final seal is achieved by a resinous layer of hydrophobic monomers.
"Universal", "multimode" or "multipurpose" adhesive systems are increasingly used due to the improvement in their composition by having the 10-MDP (methacryloyloxydecyl dihydrogen phosphate) molecule, in addition to other monomers. The functional phosphate ester monomer (10MDP) was already part of the composition of selfetching adhesive systems (Clearfil SE-2 steps). Its phosphate group has the potential for interaction with hydroxyapatite and is capable of forming strong ionic bonds with calcium due to the relatively low rate of calcium dissolution contributing significantly to the durability of the restorations.

In addition, the 10-MDP monomer enables polar behavior which is favorable to adhesion, and protects the collagen fibers through the formation of MDPcalcium salts ${ }^{8}$. Therefore, studies demonstrating dentin permeability after the use of these simplified "universal" materials compared to the already established 3-step etch-and-rinse and 2-step selfetch systems are needed. It is interesting to note that this analysis is important mainly in conditions of demineralized dentin that has mineral depletion with loss of $\mathrm{Ca}$ and $\mathrm{P}$.

With regard to this concept, the literature has shown that even after the photopolymerization, fluid transudation through the polymerized adhesives is observed ${ }^{4,10}$ and that these dentin adhesives are susceptible to surface degradation by the erosive challenge. The presence in the oral cavity of acids of intrinsic or extrinsic origin ${ }^{11}$ may result in dental erosion, affecting dental tissues (enamel/dentin) and degrading restorative materials ${ }^{12}$.

Knowing that the dentinal fluid rate changes when hybrid coatings are applied after erosive challenges ${ }^{5}$, we became interested in learning about the behavior regarding hydraulic conductance of simplified universal systems. It is important to evaluate the intrinsic water permeability in adhesive systems because it is known to have a significant effect on the quality of bond strength and adhesive interface ${ }^{13}$.

The aim of this in vitro study was therefore to use the hydraulic conductance test to evaluate the influence of the use of different adhesive systems on dentin permeability immediately after application and after being submitted to the erosive challenge. The null hypotheses tested are: there is no statistically significant difference in dentin permeability 1) immediately after the application of different adhesive systems, and 2) after being submitted to erosive challenge. 


\section{MATERIALS AND METHODS}

\section{Specimen preparation}

Fifty bovine incisors were cleaned and stored in distilled water, which was changed weekly until use, for a period not exceeding 6 months.

The teeth were sectioned, under constant water cooling, below the cementoenamel junction with a diamond disc (Dremel, Campinas, SP, Brazil) coupled to a high-rotation lathe (Nevoni, São Paulo, Brazil) for root removal.

A trephine drill $(6 \mathrm{~mm}$ internal $\varnothing)$ adapted to a cutting machine (Micro Mill - Washington, USA) under abundant irrigation, was used to prepare circular samples of enamel and dentin obtained from the flatter central portion of the buccal surface. For enamel removal and standardization of dentin thickness at $1 \mathrm{~mm}$, the samples were worn in a circular polishing machine (DP-10, Panambra, São Paulo, SP, Brazil) with P600, P800, P1200 granular silicon carbide sandpaper (Fepa P, Extec, Enfield, CT, USA) and sanded to P2400 granularity (Fepa P, Extec, Enfield, CT, USA) under constant water cooling.

\section{Opening of the dentinal tubules}

To remove the smear layer and expose dentinal tubules, the samples were immersed in $37 \%$ phosphoric acid solution for $30 \mathrm{~s}$, washed with deionized water for $30 \mathrm{~s}$ and stored in $0.1 \%$ thymol.

\section{Dentin permeability}

Dentin permeability was determined using the apparatus, split chamber model, THD 03 (ODEME Equipamentos médicos e odontológicos Ltda, Joaçaba, SC, Brazil) (Fig. 1). Dentin permeability was established by hydraulic conductance (HC, Lp) using the following formula: $\mathrm{Lp}=\mathrm{Q} /(\mathrm{SA} . \mathrm{P})$, where $\mathrm{L} p=$ hydraulic conductance expressed in $\mu 1 . \mathrm{cm}^{-2}$. $\mathrm{min}^{-1} \cdot \mathrm{cmH}_{2} \mathrm{O}^{-1}, \mathrm{Q}=$ infiltration rate in $\mu \mathrm{L} \cdot \mathrm{min}^{-1}$, $\mathrm{SA}=$ surface area exposed to filtration in $\mathrm{cm}^{2}$, $\mathrm{P}=$ hydrostatic pressure across dentin in $\mathrm{cmH}_{2} \mathrm{O}^{5,14}$. Hydraulic conductance was measured at three times: after removal of the smear layer - initial (HC-0) (PI), after treatments (application of adhesive systems) (HC-1) and after erosive challenge (HC-2).

To determine hydraulic conductance, the samples were placed between two rings that enabled the standardization of the available dentin area for deionized water filtration $\left(0.03801 \mathrm{~cm}^{2}\right)$ and adequate sealing. The pulp face remained in contact with the fluid (deionized water) under a pressure of $703 \mathrm{~cm} \mathrm{H}_{2} \mathrm{O}^{15}$ and the external side faced the environment, according to the dental structure. Fluid filtration through the dentin was followed for 2 min by linear displacement of an air bubble

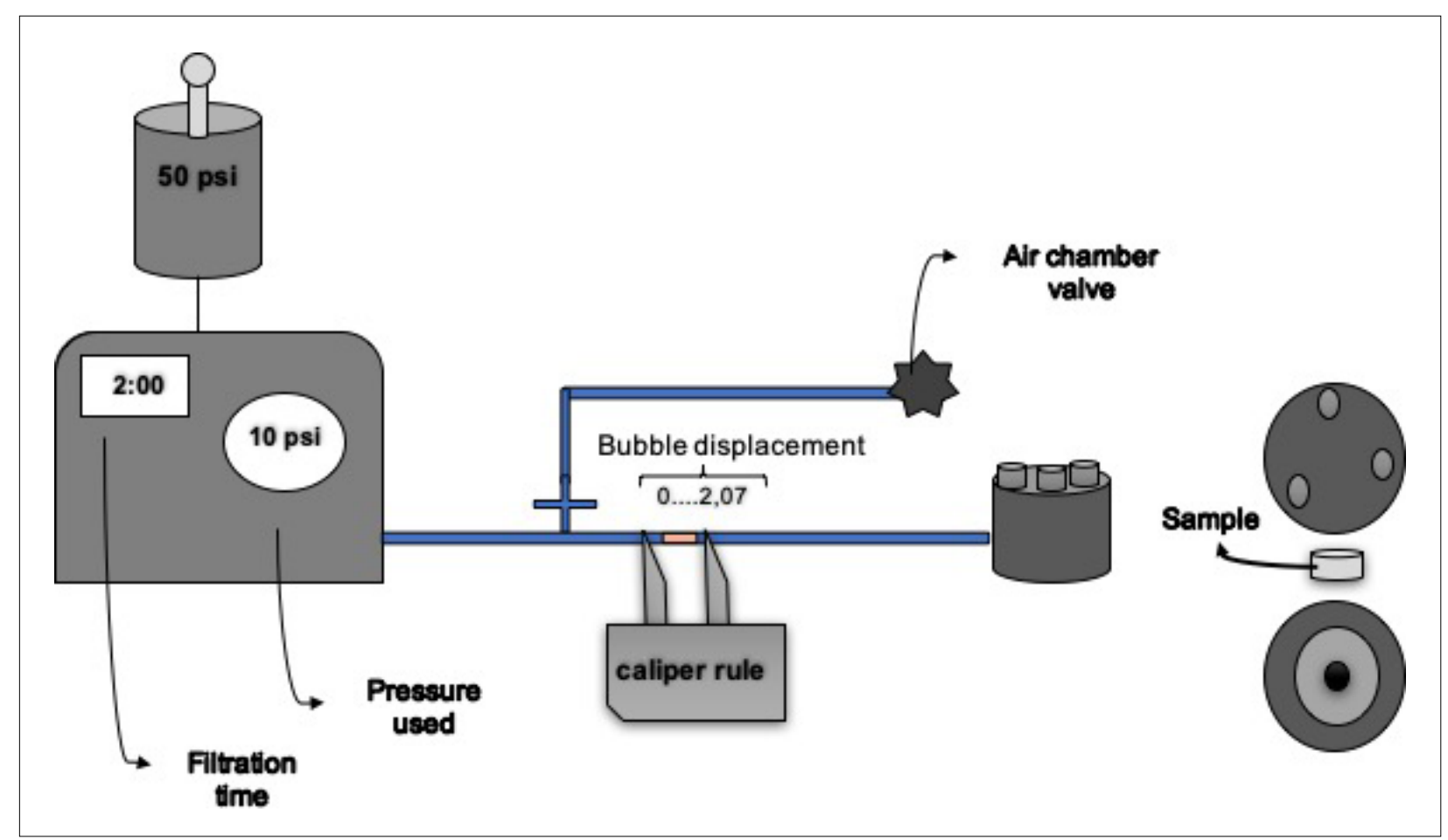

Fig. 1: Schematic drawing of the permeability device 
inserted into the glass capillary using a digital caliper. This glass capillary (internal volume $75 \mu 1$ and length $101 \mathrm{~mm}$ ) is responsible for connecting the water reservoir and the perfusion chamber. Three consecutive measurements of the linear displacement of the bubble were recorded for each sample and the average of these measurements was used to determine dentin permeability (Fig. 1).

\section{Distribution of experimental groups}

After reading the (HC-0), the samples were divided into 5 groups ( $\mathrm{n}=10$ each) so that they had similar average values of initial hydraulic conductance. Adhesive systems were applied according to the manufacturers' instructions (Table 1). After the treatments, the specimens were stored in deionized water at $37 \pm 1^{\circ} \mathrm{C}$ for $24 \mathrm{~h}$.

\section{Erosive challenge}

The erosive challenge was performed on the external face (vestibular) of the specimens by four daily cycles of erosion for five days. Each cycle consisted of immersing the samples in $0.3 \%$ citric acid solution at $\mathrm{pH} 2.3$ for 2 minutes, followed by washing in ultrapure water and immersion in artificial saliva $(\mathrm{pH}=7)$ for 1 hour, ${ }^{16}$ a formulation proposed by Gohring et al. ${ }^{17}$ Before starting a new cycle, the samples were washed with ultrapure water and new solutions of citric acid and artificial saliva were used. The sequence of 4 cycles of erosive challenge and 20 hours of immersion in artificial saliva was repeated for 5 consecutive days. After the erosive challenge, the samples were kept in ultrapure water at $37 \pm 1{ }^{\circ} \mathrm{C}$ for $24 \mathrm{~h}$.

\begin{tabular}{|c|c|c|c|}
\hline GROUPS & MATERIAL/LOT & COMPOSITION & APPLICATION METHOD \\
\hline CSB & $\begin{array}{l}\text { Clearfil SE Bond } \\
\text { Primer -L: 01245A } \\
\text { Adhesive -L: } \\
\text { 01882A }\end{array}$ & $\begin{array}{l}\text { Primer: } 10 \text {-Methacryloxydecyl dihydrogen- } \\
\text { phosphate (MDP), 2-hydroxyethyl methacrylate } \\
\text { (HEMA), camphorquinone hydrophilic } \\
\text { dimethacrylate, N, N - diethanol-P-toluidine, } \\
\text { water } \\
\text { Adhesive: MDP, bisphenol A glycidyl } \\
\text { dimethacrylate (Bis-GMA), HEMA, hydrophobic } \\
\text { dimethacrylate, camphorquinone, N, N - } \\
\text { diethanol-P-toluidine, silanized colloidal silica }\end{array}$ & $\begin{array}{l}\text { - Drying with absorbent paper. } \\
\text { - } \text { Primer application for } 20 \mathrm{~s} \text {. } \\
\text { - } \text { Adhesht air blast for } 5 \mathrm{~s} \text {. } \\
\text { - Light air blast for } 5 \mathrm{~s} \text {. } \\
\text { - Light cure for } 10 \mathrm{~s} \text {. }\end{array}$ \\
\hline SBU & $\begin{array}{l}\text { Single Bond } \\
\text { Universal - 3M -L: } \\
1432500600\end{array}$ & $\begin{array}{l}\text { Bisphenol A diglycidyl ether dimethacrylate } \\
\text { (Bis-GMA), 2-hydroxyethyl methacrylate, } \\
\text { silica treated with silicon, ethyl alcohol, } \\
\text { decamethylene dimethacrylate, water, } \\
\text { 1,10-decanediol methacrylate phosphate, } \\
\text { acrylic copolymer and itaconic acid, } \\
\text { camphoroquinone, N, N - dimethylbenzocaine, } \\
\text { 2-dimethylamonoethyl methacrylate, methyl } \\
\text { ethyl ketone }\end{array}$ & $\begin{array}{l}\text { - Surface drying with absorbent paper. } \\
\text { - Active application of the adhesive with } \\
\text { a disposable applicator for } 20 \mathrm{~s} \text {. } \\
\text { - Light air blast for } 5 \mathrm{~s} \text {. } \\
\text { - Light cure for } 10 \mathrm{~s} \text {. }\end{array}$ \\
\hline SB2 & $\begin{array}{l}\text { Single Bond } 2-3 M \\
\text { L: N587475 }\end{array}$ & $\begin{array}{l}\text { Ethanol, Bis-GMA, Silane Treated with } \\
\text { Silica Particle, 2-Hydrosethylmethacrylate, } \\
\text { Glycerol 1,3 Dimethacrylate, Acrylic Acid } \\
\text { Copolymer, and Itaconic Acid and Diurethane } \\
\text { Dimethacrylate }\end{array}$ & $\begin{array}{l}\text { - Surface drying with absorbent paper. } \\
\text { - } \text { for } 15 \mathrm{~s} \text {. } \\
\text { - Washing with water for } 15 \mathrm{~s} \text { and } \\
\text { drying with absorbent paper. } \\
\text { - Two consecutive Single Bond } 2 \text { layers } \\
\text { actively applied for } 15 \mathrm{~s} \text {. } \\
\text { - Light air blast for } 5 \mathrm{~s} \text {. } \\
\text { - Light cure for } 10 \mathrm{~s}\end{array}$ \\
\hline SM & $\begin{array}{l}\text { Scotchbond } \\
\text { Multipurpose - 3M } \\
\text { Primer- L: } \\
\text { 1502200616 } \\
\text { Adhe- } \\
\text { sive-L:1411401017 }\end{array}$ & $\begin{array}{l}\text { Primer: 2-hydroxyethyl methacrylate (HEMA) } \\
\text { and polyalkene acid } \\
\text { Adhesive: bismethacrylate (1-methylethylidene) } \\
\text { bis[4,1-fenilenooxi (2-hydroxy-3,1-propanediol)] } \\
\text { and 2-hydroxyethyl methacrylate }\end{array}$ & $\begin{array}{l}\text { - Surface drying with absorbent paper. } \\
\text { - } \text { Application of } 37 \% \text { phosphoric acid } 15 \mathrm{~s} \text {. } \\
\text { - Washing for } 15 \mathrm{~s} \text { and drying with } \\
\text { - } \text { Primerbent paper. } \\
\text { - } \text { Light air blast for } 5 \mathrm{~s} \text {. } \\
\text { - } \text { Adhesive application. } \\
\text { - Light cure for } 10 \mathrm{~s} \text {. }\end{array}$ \\
\hline C & NO TREATMENT & Control & $\begin{array}{l}\text { - Storage in distilled water during all the } \\
\text { studied periods. }\end{array}$ \\
\hline
\end{tabular}




\section{Permeability percentages}

The initial permeability calculated from HC-0 was considered to be $100 \%$ for each sample analyzed. The dentin percentage permeability for each sample was calculated after the treatment (\%PPT) and after erosive challenge (\%PPEC), and each sample was its control. To obtain these permeability values, the following formula was applied: $\% \mathrm{P}=(\mathrm{Lp} .100) /$ Lpinitial, where $\% \mathrm{P}=$ percentage of permeability regarding the initial permeability, $\mathrm{Lp}=$ hydraulic conductance at each moment, Lpinitial $=$ initial hydraulic conductance (CH- 0 ) considered after removal of the smear layer and tubular opening.

Scanning electron microscope (SEM) micrographs Micrographs (3000x and 5000x) were obtained after the application of the adhesive systems and after the erosive challenge, to observe the behavior of different types of treatment on dentin. To do so, the samples were dried in a graded series of alcohol and desiccator for $24 \mathrm{~h}$. Subsequently, the samples were placed on an aluminum stub with the aid of a conductive carbon tape and metalcoated in a SC7620 Sputter Coater (Emitech, FEI, Czech Republic) employing 25 KV. Samples were analyzed by capturing the images through software coupled to the SEM (Inspect 550, Fei).

\section{Statistical analysis}

The average values (standard deviations) and medians of \%PPT and \%PPEC were calculated.

The Kruskal-Wallis test and Mann-Whitney post hoc test with Bonferroni correction were used to test the hypothesis that the groups were different in \%PPT and \%PPEC. The Wilcoxon test was employed to test the hypothesis that there was no significant difference in the dentin permeability change of each material between \%PPT and \%PPEC. The adopted significance level was $5 \%$. The statistical program used was SPSS 24.0 (IBM, Armonk, NY, USA).

\section{RESULTS}

\section{Dentin permeability analysis}

Table 2 shows the average values of \%PPT and $\%$ PPEC for the different groups. A significant reduction in permeability is observed after the use of adhesives $(p<0.05)$. From the initial values of hydraulic conductance, it is verified that permeability was reduced in all the systems by more than $80 \%$. In demineralized dentin, both the self-etch and totaletch systems exhibited similar immediate behaviors, differing only from the untreated demineralized group. However, on the same substrate, after the erosive challenge, a significant increase in permeability was found for self-etch adhesives (CSB and SBU) (Table 2).

\section{Scanning Electron Microscopy (SEM) \\ Analysis}

Micrographs (3000 and $5000 \mathrm{X}$ ) of the different experimental groups showed the presence of porosity and irregularities, with the presence of valleys and depressions in the dentin surface, even after the application of adhesive systems. The degradation of the adhesives after erosive challenge demonstrated greater uniformity of the surface layer (Fig. 2). The demineralized dentin had evidently open, exposed collagen fibers, and after erosion, the presence of smear layer.

\section{DISCUSSION}

Several adhesive systems are available, but their influence on dentinal tubule sealing, and consequently

Table 2. Mean values (standard deviation) of the percentage of median dentin permeability after treatment and post-erosive challenge.

\begin{tabular}{|c|c|c|c|c|c|c|}
\hline \multirow[t]{2}{*}{ Groups } & \multicolumn{2}{|c|}{$\begin{array}{c}\% \mathrm{P} \\
\text { Post-treatment }\end{array}$} & \multirow{2}{*}{$\begin{array}{c}\% \\
\text { Permeability } \\
\text { Reduction }\end{array}$} & \multicolumn{2}{|c|}{$\begin{array}{c}\% \mathrm{P} \\
\text { Post-erosive challenge }\end{array}$} & \multirow{2}{*}{$\begin{array}{c}\% \\
\text { Permeability } \\
\text { Reduction }\end{array}$} \\
\hline & Means (SD) & Median (IC 5-95\%) & & Means (SD) & Median (IC 5-95\%) & \\
\hline CSB & $7.97(6.31)^{\mathrm{aA}}$ & $5.92(3.45-12.49)$ & 92.0 & $10.65(8.43)^{\mathrm{bA}}$ & $7.30(4.61-16.68)$ & 89.3 \\
\hline SBU & $7.98(5.26)^{a A}$ & $6.95(4.21-11.75)$ & 92.0 & $12.12(9.16)^{\mathrm{bA}}$ & $10.52(5.56-18.68)$ & 87.8 \\
\hline SB2 & $10.38(10.62)^{\mathrm{aA}}$ & $6.54(2.78-17.99)$ & 89.6 & $11.94(9.90)^{\mathrm{aA}}$ & $7.22(4.85-19.02)$ & 88.0 \\
\hline SM & $16.10(10.19)^{\mathrm{aA}}$ & 14.52 (8.80-23.39) & 83.9 & $15.61(9.84)^{\mathrm{aA}}$ & $12.05(8.57-22.66)$ & 84.3 \\
\hline C & $104.29(13.50)^{a B}$ & $104.15(4.61-16.68)$ & -4.29 & $157.93(77.49)^{\text {ав }}$ & $143.38(102.50-213.37)$ & $-57,9$ \\
\hline
\end{tabular}

*Different lowercase letters, statistical difference between columns and different uppercase letters, statistical difference between lines ( $p<0.05$ ) 


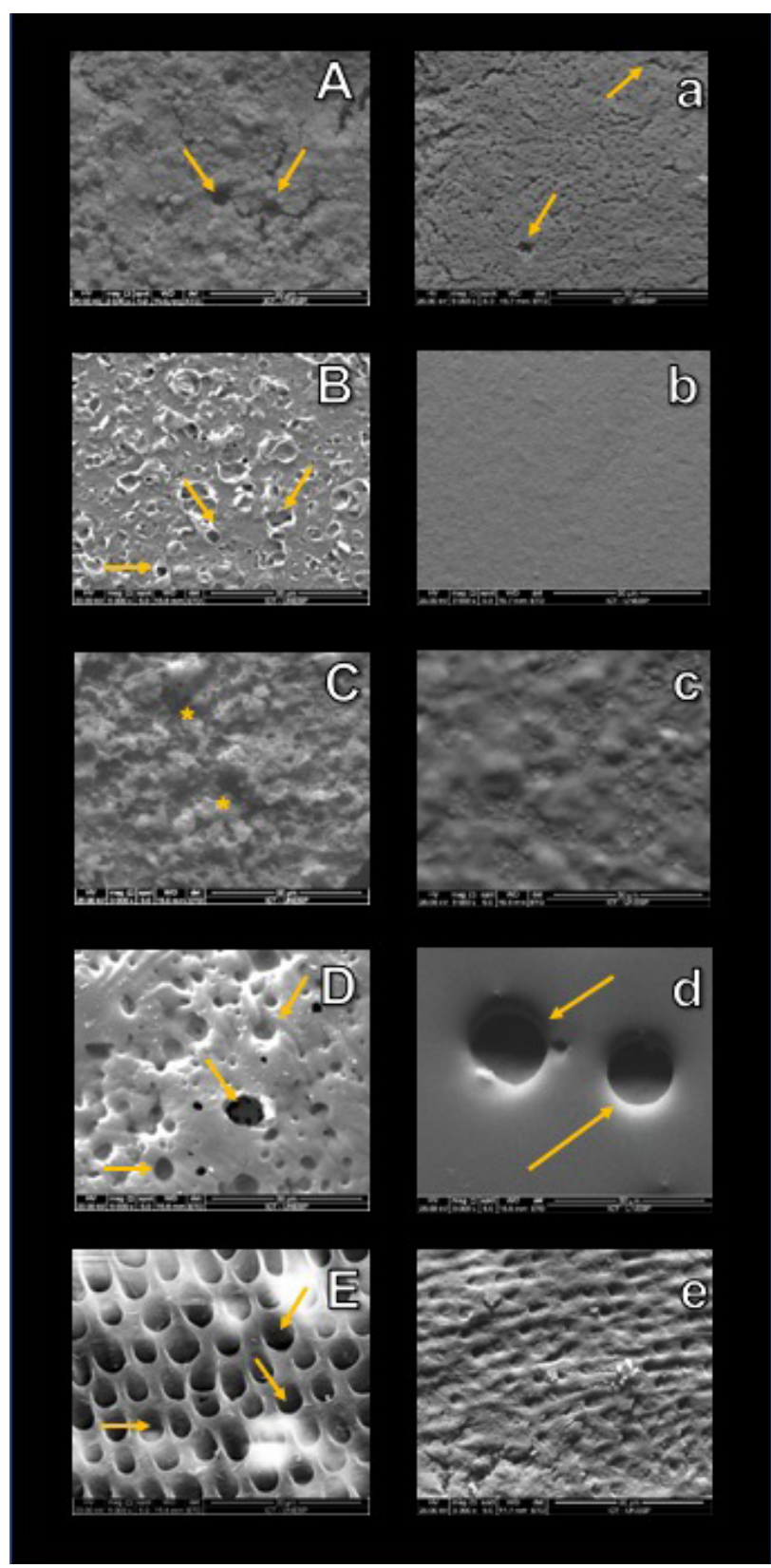

Fig. 2: Micrographs of the surfaces treated with the different adhesive systems before (uppercase letters) and after (lowercase letters) the erosive cycle: $C S B-A$. Irregular layer, porosity. a. Eroded layer presenting microporosity (arrows). $S B U-B$. Numerous pores $b$. More regular eroded surface layer. $S B 2-C$. Irregular layer with valleys and depressions (asterisk). c. More regular eroded layer. $S M-D$. Layer with numerous pores (arrow). d. Layer with dilated pores (arrow). C-E. Tubule opening and exposure of collagen fibers (arrow). e. Eroded dentin.

on dentinal permeability, is still a relevant object of study. In the present study, the first hypothesis was rejected, because after being applied on dentin, all the adhesive systems promoted a significant reduction in dentin permeability compared to the control group, without statistical differences among them. The second null hypothesis was also rejected, because after the erosive challenge, there was an increase in dentin permeability of the self-etching (CSB) and universal (SBU) systems.

Most studies have evaluated dentinal permeability by imaging techniques such as scanning electron microscopy (SEM), ${ }^{13,18}$ transmission electron microscopy (TEM) $)^{7,13}$, and confocal laser microscopy ${ }^{13}$. The evaluation of hydraulic conductance has been suggested as an adequate way to quantify dentin permeability. The evaluation of hydraulic conductance, even when associated with the intra-pulp pressure simulation ${ }^{13}$, provides significant information regarding the behavior of materials on dentin. However, few studies have evaluated hydraulic conductance after dentin treatment with different adhesive systems.

As observed in the literature, regardless of the composition of the materials used, the adhesive systems [conventional, self-etching (multiple bottles) and universal (single bottle)] did not differ significantly and did not completely seal dentinal tubule fluid percolation ${ }^{18}$, corroborating the study by Carvalho et al. ${ }^{15}$ In vitro and in vivo evaluations demonstrate that adhesive systems applied on the dentin allow the dentin fluid to pass through the polymerized resinous materials ${ }^{3}$, but their application significantly reduces dentin permeability ${ }^{15,16}$.

Changes in the chemical and molecular structure of the dentin interface are observed with the use of 3-step adhesives such as Scotchbond MultiPurpose or OptiBond FL and 2-step self-etching adhesives $^{3}$. It has been reported that Clearfil SE, whose acidic primer is covered with a solvent-free, dimethacrylate-rich adhesive, could present a longer life than simplified adhesives that allow greater dentin fluid passage through the resin ${ }^{3}$. Application of the simplified adhesive system SB2 was expected to present higher permeability than the other systems studied. Being a simplified system, it contains solvents and hydrophilic components such as the polyalkene acid polymer, which has multiple pendant carboxylic acids along with a linear skeleton and tends to bind water to the adhesive as well as to prevent its penetration into the interfibrillar spaces, due to its high molecular weight ${ }^{14}$. However, a factor that contributed to the good performance of the simplified conventional adhesive was the fact that 2 layers of the adhesive were actively applied, waiting for solvent 
evaporation, as recommended by the manufacturer. It is known that more than one layer of adhesive is recommended because a single layer promotes lower $\mu$ TBS and higher permeability values ${ }^{18}$.

Self-etching systems are widely indicated for prehybridization and sealing of dentin before indirect adhesive procedures 19 because they decrease sensitivity and protect the pulp by partially sealing the dentin ${ }^{3}$. Due to their wide acceptance and good clinical and laboratory results ${ }^{19}$, two-bottle (CSE) and singlebottle (SBU) self-etching systems were expected to present better dentinal sealing values. Kamazu et al. ${ }^{20}$ observed that two-step etch-and-rinse adhesive (Single Bond Plus) showed relatively stable dentin bond performance under all degradation conditions, and the three-step etch-and-rinse adhesive showed decreased dentin shear bond strength with prolonged degradation. The universal adhesive [Scotchbond Universal] used in normal dentin did not show any significant decrease in shear bond strength from the baseline under any degradation condition.

However, in our study, the smear layer was completely removed and the dentinal tubules were fully opened in order to evaluate hydraulic conductance, according to the studies that evaluate dentinal permeability 5 . In agreement with the methodology employed, in cases of dental erosion, it has been observed that dentin has a certain degree of demineralization, and microscopic evaluations show that teeth with dentin hypersensitivity present eight times more dentinal tubules per area unit and tubular diameter twice the size compared to non-sensitive teeth ${ }^{21}$. Therefore, the self-etching adhesives with 10-MDP could not react chemically with the mineral component of dentin ${ }^{22}$, not establishing a strong chemical adhesion of the phosphate group with hydroxyapatite. Simplified adhesives used in etch-and-rinse mode are mainly characterized by hydrolysis and collagen degradation, while in self-etch mode, mainly hydrolysis of the polymeric matrix is observed ${ }^{23}$. The degradation of the hybrid layer occurs through the enzymatic degradation of its collagen fibrils by endogenous dentinal enzymes, such as the matrix metalloproteinases (MMPs) and cysteine cathepsins, and the leaching of the resin from the hybrid layer ${ }^{4}$.
After the erosive challenge, chemical stress became more evident. The mechanical barrier failure for the CSB and SBU systems applied to demineralized dentin occurred due to the formation of a weak ionic bond of functional monomers with calcium. In contrast, the micro-tags formed by acid etching/ adhesive and the performance of a judicious technique promoted greater stability of dentinal tubule sealing for the SM and SB2 groups. After being submitted to the erosive challenge, restorative materials can show superficial degradation with reduction of surface roughness and microhardness ${ }^{24}$. The micrographs of the present study illustrated that the adhesive systems presented porosities, demonstrated by the presence of bubbles and cracks, becoming semi-permeable membranes when compared to the control sample (total opening of the tubules). And after the erosive challenge, the samples presented greater surface degradation.

Although single-bottle self-etching adhesive systems are more susceptible to hybrid layer degradation ${ }^{23}$ and consequently to increased dentin permeability than are other types of adhesive systems, the 24-hour 5-day periods of the erosive challenge may not have been enough for hydrolytic degradation to occur and to result in a significant increase in permeability. Some studies suggest hydrolytic activity during the 6 months of water storage ${ }^{25}$, which means that from that time on, water must have been able to travel freely through the hybrid layer.

The results of this study enabled us to observe that, for immediate use, all materials when applied to demineralized dentin appeared to work as a mechanical barrier, presenting similar behavior. However, in the long-term, one must carefully analyze not only the monomeric composition of the materials, but also the quality of the substrate. Mainly when facing eroded dentin, the permeability of the substrate treated with self-etching systems may be compromised.

In conclusion, the use of conventional, self-etching, and universal adhesive systems reduces immediate dentin permeability by more than $80 \%{ }^{16}$. The high degree of dentin demineralization may contribute to the increase in the permeability of universal and self-etching systems subjected to erosion challenge. 


\section{DECLARATION OF CONFLICTING INTERESTS}

The authors declared no potential conflicts of interest with respect to the research, authorship, and/or publication of this article.

\section{FUNDING}

The present study was supported in part by the Coordenação de Aperfeiçoamento de Pessoal de Nível Superior - Brasil (CAPES) - Finance Code 001" and FAPEMA Grants-in-Aid for Scientific Research, n. BEPP01136/15 and 05254/15.

\section{REFERENCES}

1. Mjör IA. Dentin permeability: the basis for understanding pulp reactions and adhesive technology. Braz Dent $\mathrm{J}$ 2009;20:3-16.

2. Liu XX, Tenenbaum HC, Wilder RS, Quock R, Hewlett ER, Ren YF. Pathogenesis, diagnosis and management of dentin hypersensitivity: an evidence-based overview for dental practitioners. BMC Oral Health. 2020;20:220.

3. Abu Nawareg MM, Zidan AZ, Zhou J, Chiba A et al. Adhesive sealing of dentin surfaces in vitro: A review. Am J Dent 2015;28:321-332.

4. Breschi L, Maravic T, Cunha SR, Comba A et al. Dentin bonding systems: From dentin collagen structure to bond preservation and clinical applications. Dent Mater. 2018;34:78-96.

5. Oliveira TA, Anágua-Bravo E, Aoki IV, Scaramucci T, Sobral MAP. Chemical and mechanical resistance of novel experimental hybrid coatings on dentin permeability. Microsc Res Tech. 2020;84:163-170.

6. Tjäderhane L. Dentin Bonding: Can We Make it Last? Oper Dent 2015;40:4-18.

7. Chersoni S, Suppa P, Grandini S, Goracci C et al. In vivo and in vitro permeability of one-step self-etch adhesives. J Dent Res 2004;83:459-464.

8. Carrilho E, Cardoso M, Marques Ferreira M, Marto CM, Paula A, Coelho AS. 10-MDP Based Dental Adhesives: Adhesive Interface Characterization and Adhesive Stability-A Systematic Review. Materials (Basel). 2019;12:790.

9. Sung YH, Son HH, Yi K, Chang J. Elemental analysis of caries-affected root dentin and artificially demineralized dentin. Restor Dent Endod. 2016;41:255-261.

10. Cadenaro M, Maravic T, Comba A, Mazzoni A et al. The role of polymerization in adhesive dentistry. Dent Mater. 2019;35:e1-e22.

11. Marshall TA. Dietary assessment and counseling for dental erosion. J Am Dent Assoc 2018;149:148-152.

12. Alghilan MA, Blaine Cook N, Platt JA, Eckert GJ et al. Susceptibility of restorations and adjacent enamel/dentine to erosion under different salivary flow conditions. J Dent 2015;43:1476-1482.

13. Pucci CR, Gu L-S, Zeng C, Gou Y-P et al. Susceptibility of contemporary single-bottle self-etch dentine adhesives to intrinsic water permeation. J Dent 2017;66:52-61.

14. Sahin C, Cehreli ZC, Yenigul M, Dayangac B. In vitro permeability of etch-and-rinse and self-etch adhesives used for immediate dentin sealing. Dent Mater J 2012;31:401408 .

\section{CORRESPONDENCE}

Leily Macedo Firoozmand

Av. dos Portugueses, 1966 - Vila Bacanga,

CEP 65080-805 - São Luís - MA - Brasil

leilyfiroozmand@hotmail.com

15. Carvalho A, de Oliveira M, Nikaido T, Tagami J et al. Effect of adhesive system and application strategy on reduction of dentin permeability. Braz Oral Res 2012;26:397-403.

16. João-Souza SH, Machado AC, Lopes RM, Zezell DM, Scaramucci T, Aranha ACC. Effectiveness and acid/tooth brushing resistance of in-office desensitizing treatments-A hydraulic conductance study. Arch Oral Biol. 2018;96:130136.

17. Göhring TN, Zehnder M, Sener B, Schmidlin PR. In vitro microleakage of adhesive-sealed dentin with lactic acid and saliva exposure: A radio-isotope analysis. J Dent 2004;32:235-240.

18. Carvalho EM, Stanislawczuk R, Costa T, Moura SK, Loguercio A, Bauer J. Multiple Adhesive Layering Influence on Dentin Bonding and Permeability. Eur J Prosthodont Restor Dent. 2017;25:2-8.

19. van den Breemer C, Gresnigt M, Özcan M, Kerdijk W, Cune MS. Prospective Randomized Clinical Trial on the Survival of Lithium Disilicate Posterior Partial Crowns Bonded Using Immediate or Delayed Dentin Sealing: Short-term Results on Tooth Sensitivity and Patient Satisfaction. Oper Dent. 2019;44:E212-E222.

20. Kawazu M, Takamizawa T, Hirokane E, Tsujimoto A, Tamura T, Barkmeier WW, Latta MA, Miyazaki M. Comparison of dentin bond durability of a universal adhesive and two etch-and-rinse adhesive systems. Clin Oral Investig. 2020;24:2889-2897.

21. Absi EG, Addy M, Adams D. Dentine hypersensitivity. A study of the patency of dentinal tubules in sensitive and nonsensitive cervical dentine. J Clin Periodontol 1987;14:280284.

22. Oliveira BMB, Ubaldini ALM, Baesso ML, Andrade LHC et al. Chemical interaction and interface analysis of selfetch adhesives containing 10-MDP and methacrylamide with the dentin in noncarious cervical lesions. Oper Dent 2018;43:E253-E265.

23. Feitosa VP, Sauro S, Zenobi W, Silva JC, Abuna G, Van Meerbeek B, Sinhoreti MAC, Correr AB, Yoshihara K. Degradation of Adhesive-Dentin Interfaces Created Using Different Bonding Strategies after Five-year Simulated Pulpal Pressure. J Adhes Dent. 2019;21:199-207.

24. Guedes APA, Oliveira-Reis B, Catelan A, Suzuki TYU, Briso ALF, Santos PHD. Mechanical and surface properties analysis of restorative materials submitted to erosive challenges in situ. Eur J Dent. 2018;12:559-565.

25. Fugolin AP, Lewis S, Logan MG, Ferracane JL, Pfeifer CS. Methacrylamide-methacrylate hybrid monomers for dental applications. Dent Mater. 2020;36:1028-1037. 